\title{
Epidemiology of Traumatic Myiasis due to Chrysomya bezziana in Indonesia
}

\author{
Wardhana $\mathrm{AH}^{1}$, Abadi $\mathrm{I}^{2}$, Cameron $\mathrm{MM}^{3}$, Ready $\mathrm{PD}^{3,4}$, Hall $\mathrm{MJR}^{4}$ \\ ${ }^{1}$ Parasitology Department, Indonesian Research Center for Veterinary Science, Bogor, Indonesia \\ ${ }^{2}$ Food Security and Livestock Agency, Kediri, Indonesia \\ ${ }^{3}$ Department of Disease Control, London School of Hygiene and Tropical Medicine, London, UK \\ ${ }^{4}$ Life Sciences Department, Natural History Museum, London, UK \\ E-mail: Wardhana24id@yahoo.com
}

(received 03-01-2018; revised 05-02-2018; accepted 20-02-2018)

\begin{abstract}
ABSTRAK
Wardhana AH, Abadi I, Cameron MM, Ready PD, Hall MJR. 2018. Epidemiologi myiasis traumatika yang disebabkan oleh lalat di Indonesia. JITV 23(1): 45-60. DOI: http://dx.doi.org/10.14334/jitv.v23i1.1617

Epidemiologi myiasis traumatika di Indonesia dipelajari melalui larva lalat yang dikoleksi dari ternak di berbagai daerah dengan melakukan surveilan pasif yang melibatkan Pos Kesehatan Hewan (Poskeswan). Data bulanan kasus myiasis di Kediri Jawa Timur pada tahun 2006-2009 juga dianalisis untuk memperoleh gambaran kejadian musiman myiasis di daerah tersebut. Larva yang dikoleksi dari 260 kasus myiasis di berbagai daerah dan 341 kasus di Kediri diidentifikasi. Berdasarkan hasil identifikasi, seluruh penyebab myiasis traumatika di Indonesia adalah lalat Old World Screwworm (OWS), Chrysomya bezziana (Diptera : Calliphoridae) kecuali lima kasus pada ayam yang disebabkan oleh spesies lalat Musca sp. Jumlah kasus myiasis traumatika setiap bulan di Kediri sangat bervariasi, namun demikian peningkatan kasus secara nyata terjadi pada bulan Januari dan Desember pada saat musim hujan. Jumlah kasus infestasi larva OWS tertinggi pada studi ini adalah sapi dan kambing. Hasil ini membuktikan bahwa ternak sapi memiliki resiko terserang myiasis traumatika lebih tinggi dibandingkan ternak yang lain. Vulva dan umbilikus (tali pusar) adalah bagian tubuh yang paling sering terserang myiasis dan memiliki korelasi positif dengan proses beranak. Analisis DNA mitokondria terhadap 176 sampel membuktikan bahwa marka ini mampu digunakan untuk mendeteksi adanya multi-infestasi, namun tidak dapat menunjukkan korelasi positif antara garis keturunan tertentu dengan inangnya. Kombinasi iklim Indonesia yang terletak di garis katulistiwa dan sistem peternakan yang masih traditional menjadi faktor utama berkembangnya lalat OWS sepanjang tahun. Apabila myiasis tidak mendapat perhatian, maka akan menjadi ancaman peternakan di Indonesia termasuk menjadi masalah terhadap kesejahteraan para peternak. Data epidemiologi pada studi ini merupakan data myiasis traumatika yang cukup lengkap dan menjadi studi yang penting dalam mendukung program manajemen hama yang terintegrasi.
\end{abstract}

Kata Kunci: Myiasis, Mitokondria, Chrysomya bezziana, Epidemilogi

\section{ABSTRACT}

Wardhana AH, Abadi I, Cameron MM, Ready PD, Hall MJR. 2018. Epidemiology of traumatic myiasis due to Chrysomya bezziana in Indonesia. JITV 23(1): 45-60. DOI: http://dx.doi.org/10.14334/jitv.v23i1.1617

Epidemiology of traumatic myiasis in Indonesia was studied by the widespread collection of fly larvae from infested livestock in passive case detection surveys involving veterinary clinics. In addition, monthly data from Kediri regency in Eastern Java were analysed from 2006-2009 to explore the seasonality of myiasis. Larvae from a total of 260 cases from the nationwide survey and 341 cases from Kediri were identified. Except for 5 cases of chicken infestation due to Musca species in the nationwide survey, all other cases were exclusively caused by the Old World screwworm (OWS) fly, Chrysomya bezziana (Diptera: Calliphoridae). The monthly numbers of cases at Kediri were very variable, with cases in all months, but there was statistical evidence for an increase in cases in January and December, during the rainy season. The greatest numbers of infestations recorded were from cattle and goats. The most frequently infested sites nationwide and in Kediri were the vulva and umbilicus, associated with calving, which is a major risk period for traumatic myiasis. Mitochondrial DNA typing of 176 specimens was useful for detecting multiple infestations, but no association was found between genetic lineage and host. The equatorial climate of Indonesia, combined with poor husbandry systems are factors that help to support OWS fly development year round. Even if not considered a disease of strategic importance, screwworm myiasis remains a threat to livestock production in Indonesia and a major welfare issue that requires constant interventions by farmers. The new and collated epidemiological data presented represent the most extensive survey of traumatic myiasis in Indonesia to date and provide a valuable baseline to support integrated pest management programmes.

Key Words: Myiasis, Mitochondria, Chrysomya bezziana, Epidemiology 


\section{INTRODUCTION}

The larvae of the Old World screwworm (OWS) fly, Chrysomya bezziana (Diptera: Calliphoridae), cause traumatic myiasis and remain a major problem in subSaharan Africa and Asia (Hall et al. 2016). The disease is considered to be a serious animal health and welfare problem in the central livestock regions of Indonesia, particularly in the East where livestock are raised freely in the field for their entire life, a practice called the extensive husbandry system (Partoutomo 2000). The disease is found in both traditional and commercial farms and cases occur throughout the year (Wardhana et al. 2014).

Since the first report in 1926, in Minahasa, North Sulawesi (Kraneveld \& Schaaf 1937), myiasis has continued to be a livestock problem in Indonesia, and since 1948 the fly causing most infestations has been identified as the OWS fly (Wardhana et al. 2014). However, this disease is not considered to be of strategic national importance and therefore livestock owners rather than veterinarians apply treatments that are highly diverse in manner and outcome. In particular, because effective insecticides, such as Dichlorfenthion (Gusanex $\left.{ }^{\circledR}\right)$ favoured by veterinarians, are expensive and difficult to find in the markets, less affluent rural farmers depend instead on herbal medicines to kill the larvae in the wound, such as liquid of tobacco extract and others (Sukarsih et al. 1989; Wardhana \& Diana 2014; Mustika et al. 2016; Wientarsih et al. 2017). They also traditionally used kerosene, battery carbon with motor oil, gasoline and petrol to treat myiasis (Sukarsih et al. 1989). These methods might kill the larvae, but lead to skin irritation rather than wound healing. In East Sumba, many farmers additionally used insecticides developed for control of plant pests such as Isoprocarb $50 \%$ WP (MIPCIN 50 WP $($ ), which is potentially dangerous for livestock and can cause poisoning, even death (Wardhana 2006).

Partoutomo (2000) reported three main reasons why acute outbreaks of traumatic myiasis still occur in Indonesia. Firstly, the primary myiasis agent, the OWS fly, is distributed throughout the Indonesian archipelago; secondly, the environment and warm tropical weather with high humidity are suitable for development of $C$. bezziana almost throughout the year; and thirdly, a large supply of livestock hosts are available year-round, many of which are raised in an extensive livestock management system where they are not always inspected daily and so not treated in a timely manner if infested. Based on observations on commercial farms, it was concluded that imported livestock and those raised under an extensive grazing system are at high risk for myiasis infestation (Sigit \& Partoutomo 1991; Wardhana 2006). The World Organisation for Animal Health (OIE) provides country and disease data related to animal health that is held in the World Animal Health Information Database (WAHID) interface. According to the WAHID interface, myiasis cases remain a threat in many tropical countries. For example, Malaysia provided annual reports to WAHID between 2005-2014 which indicate that myiasis due to the OWS fly persists there. However, unlike its northerly neighbour, Indonesia has not submitted information on myiasis to WAHID. Clearly, this lack of reporting gives a wrong impression of the situation, because the disease is endemic and widely distributed throughout Indonesia (Wardhana et al. 2003; Wardhana et al. 2014).

The Sterile Insect Technique (SIT) has been successfully applied to eradicate a primary myiasis agent, Cochliomya hominivorax, from the North American continent and more recently from Libya and from most countries of Central America (Welch \& Hall 2013). One of the reasons for successful eradication of C. hominivorax in Libya using the SIT was due to a good understanding of interrelated components such as epidemiology and surveillance of the disease, treatment techniques, rigorous animal inspection and quarantine, and a good communication between farmers, veterinarians and other stakeholders (Lindquist et al. 1992). Robinson et al. (2009) stated that the collection of epidemiological data is the central source of management information for SIT programmes, because the data are used to determine the status and severity of the infestations and the economic magnitude of the problem. In addition, epidemiological data are correlated with the release rate of sterile insects to maximise the effect of the programme in eradicating $C$. hominivorax (Cox \& Vreysen 2005). Trials in Papua New Guinea revealed that the SIT should also be effective against $C$. bezziana (Spradbery et al. 1989; Mahon 2002).

However, before the SIT is applied in any country, the essential first steps are to collect comprehensive baseline data, including the distribution of myiasis, assessment of ecological and genetic data and also the infestation dynamics (Hall et al. 2001; Vargas-Terán et al. 2005). Moreover, Cox \& Vreysen (2005) proposed that mapping a pest's distribution on a regional and national scale is a fundamental phase to assess the feasibility and spatial targeting of the SIT. Modelling of the distribution of the OWS fly in Indonesia was undertaken by Wardhana et al. (2014), but this included only records that could be geo-referenced. Therefore, the present study reports all known presence records by island, province and regency. It focuses on the infestation dynamics and epidemiology of OWS myiasis in Indonesia, including the seasonal dynamics in Kediri regency and potential behavioural differences between OWS flies characterised by different 
mitochondrial DNA lineages (Wardhana et al. 2012) in Banten and Kediri regencies, all on Java Island.

\section{MATERIALS AND METHODS Surveillance for}

\section{infesting fly larvae \\ myiasis of livestock and collection of}

Three kinds of surveillance were co-ordinated by the Indonesian Research Center for Veterinary Science (IRCVS), Bogor, Java Island. 'Collaborative sampling' was performed by the IRCVS and a regional team during field trips of 1-2 weeks, after which the regional team was encouraged to carry out 'Continuing sampling' following the same protocols. 'Oriented sampling' was performed solely by a regional team, based on a protocol communicated by IRCVS. All three approaches were effectively passive case detection, because livestock owners were only asked to bring infested animals to a sampling point, not to carefully screen all body parts of each of their animals for any wounds.

'Collaborative sampling' was carried out by visiting a total of 170 farms, both traditional and commercial, during three years, 2005, 2007 and 2009 on the islands of Borneo, Sumatra, Java, Lombok, Sumbawa, Sumba and Sulawesi (Figure 1). 'Oriented sampling' was undertaken on these islands and others (Madura, Timor and New Guinea) 2002-2009 by contacts in local veterinary clinics, where the staff collected larvae from cases of myiasis without any selection based on species identification. Fly larvae were sampled from wounds and preserved according to a protocol (see below) that was sent to local veterinarians, livestock agencies and Disease Investigation Centres (DICs), and all samples were then sent to the IRCVS in Bogor.

\section{Preservation and identification of fly larvae from myiasis wounds}

Larvae were collected from wounds using forceps, killed by immersion in boiling water for $c .15$ seconds (not always for 'Oriented sampling'), soaked in $80 \%$ ethanol for 15 minutes and then transferred into a tube of fresh $80 \%$ ethanol for preservation (Hall et al. 2001). The tubes were labelled with date, collector, host species, stages of larvae, wound location and capture location (village, district, regency, and province) and kept at $-20^{\circ} \mathrm{C}$. All samples were identified using a published suite of diagnostic morphological characters (Hall 2008).

\section{Seasonal dynamics of myiasis cases in Kediri regency, East Java}

Kediri regency was chosen for a seasonal study because it is in an endemic area for traumatic myiasis, with a semi-intensive husbandry system, and the local veterinary clinic had a veterinarian who was prepared to collect data throughout a four-year period. The veterinarian and his two paramedic assistants monitored and controlled animal diseases across five districts (Kandat, Ngadiluwih, Ringinrejo, Kras, and Wates), and they recorded traumatic myiasis cases on their animal health reports to the regional livestock agency each calendar month, January 2006-December 2009.

Kediri regency (Figure 1) is located near the centre of East Java province, with 26 districts and 344 villages. Its agricultural system is mixed crop-livestock farming, typically with traditional semi-intensive livestock husbandry, for which animals are released from a stable (beside the farmer's house) c. 9 am and then returned to the stable c. $4 \mathrm{pm}$. No commercial farms, typically with $>100$ livestock and involved in short-term fattening programmes, were included in our sample. In the period 2006 - 2009 the maximum and minimum annual temperatures were $33^{\circ} \mathrm{C}$ and $22^{\circ} \mathrm{C}$, respectively, and the area received an average rainfall of 1000-2000 mm per annum (BMKG 2017).

\section{Mitochondrial DNA typing}

The DNA extraction technique was performed according to (Chomczynski et al. 1997) using the DNAzol ${ }^{\circledR}$ kit (Invitrogen Corp., Carlsbad, CA, U.S.A.). Successfully extracted DNA samples were dissolved in $1 \mathrm{x}$ Tris-EDTA solution and stored at $-20^{\circ} \mathrm{C}$ until analysis.

The primers used in this study were synthesized by MWG Biotech (UK) Ltd (Milton Keynes, U.K.). The 3' terminal end of the mitochondrial gene cytochrome $b$ (cyt b) (761 base pairs (bp) of the CB fragment plus primers) was amplified using the primer pair CB1-SE (5' TATGTACTACCATGAGGACAAATATC 3') and PDR-WR04 (5' ATTTCACGCTCATTAACT 3'). 


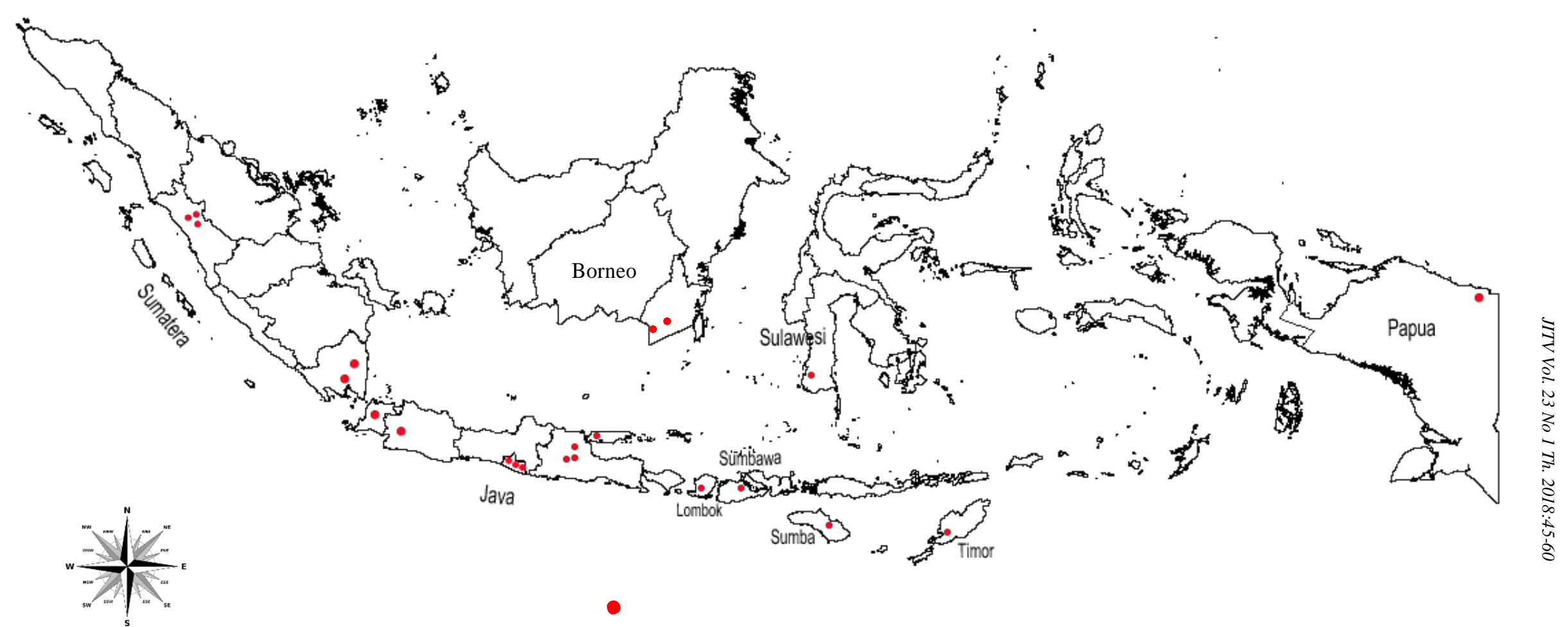


The primers used in this study were synthesized by MWG Biotech (UK) Ltd (Milton Keynes, U.K.). The 3' terminal end of the mitochondrial gene cytochrome $b$ (cyt b) (761 base pairs (bp) of the CB fragment plus primers) was amplified using the primer pair CB1-SE (5' TATGTACTACCATGAGGACAAATATC 3') and PDR-WR04 (5' ATTTCACGCTCATTAACT 3').

PCR conditions in the present study were optimized for dried specimens and those preserved in $80 \%$ ethanol (Ready et al. 2009; Wardhana et al. 2012), so that all could be properly analyzed (Hall et al. 2009a; 2009b). For this cyt $b$ fragment (CB), the PCR conditions were commenced by a 'hot start' at $80^{\circ} \mathrm{C}$, followed by an initial $3 \mathrm{~min}$. denaturation step at $94^{\circ} \mathrm{C}$, then 5 cycles of denaturation at $94^{\circ} \mathrm{C}$ for 30 seconds, annealing at $40^{\circ} \mathrm{C}$ for 30 seconds, ending with an extension step at $72^{\circ} \mathrm{C}$ for 90 second. This was followed by 35 cycles of denaturation, annealing and extension, where running parameters were those above except for a substituted annealing temperature of $44^{\circ} \mathrm{C}$. The PCR reaction was finished by a final extension step of $72^{\circ} \mathrm{C}$ for 10 minutes and subsequent holding at $4^{\circ} \mathrm{C}$. Sanger sequencing of each DNA strand used the primers CB1 and PDR-WR04, following the protocol of Ready et al. (2009).

\section{Statistical analysis}

All data were entered into a Microsoft Excel 2008 spreadsheet by date, location, host species, sex, age, and wound site. Categorical data were analysed by a Yates corrected $\chi^{2}$ (Chi Square) test in Epi Info version 6.04d (Dean 1996) to test the effect of host species, host gender and wound site on the number of infestations. Continuous data, such as number of cases in different districts, were analysed with Unistat v. 6.0 and ANOVA in Stat-View v. 5.0. The results were considered significantly different at the $95 \%$ probability level $(\mathrm{P}<0.05)$.

\section{RESULTS AND DISCUSSION}

\section{Predominance of OWS in traumatic myiasis wounds of livestock in Indonesia}

The OWS fly was found to be the predominant species responsible for traumatic myiasis (255/260; $98.1 \%$ ) in all collections from 2002-2009 (Table 1). Musca species (Muscidae) accounted for the other cases $(5 / 260 ; 1.9 \%)$, with all found in rectum wounds of chickens as part of the 'oriented sampling'. These rare cases were not considered in any further analysis.

Pre-2002 cases were discussed by Wardhana et al. (2014), and again the OWS fly predominated from the first time this species was definitively recorded (Kraneveld \& Pettinga 1949). The earliest case from 1926, reported by Kraneveld \& Schaaf (1937), is now believed to have been caused by Booponus intonsus (Calliphoridae). Only OWS cases are considered further in the current report.

\section{Geographical distribution of OWS in Indonesia}

Historical records of OWS in Indonesia were reported and discussed by Wardhana et al. (2014), but they did not include a comprehensive table of all distribution records by province and regency because their report focused on ecological niche modelling based only on presence records that could be georeferenced. The three kinds of surveillance carried out from 2002-2009 produced a total of 255 traumatic myiasis cases caused by the OWS fly in livestock from the western end to the eastern end of Indonesia. Table 1 includes these 255 cases from 22 regencies on 9 islands, which consist of records from one regency on Kalimantan (Tanah Laut), 5 regencies on Sumatra (Agam, Mungka, Payakumbuh, Lampung, Seputih Rahman), 9 regencies on Java (Banten, Sukabumi, Gunung Kidul, Klaten, Sleman, Blitar, Jember, Lamongan, Kediri), one regency on Madura (Bangkalan), one regency on Lombok (Mataram), one regency on Sumbawa (Sumbawa Besar), one regency on Sumba (East Sumba), one regency on Timor (Kupang), one regency on Sulawesi (Makassar) and one regency on New Guinea (Jayapura).

Larvae of $C$. bezziana were successfully collected from 12 regencies by 'collaborative sampling' and 'continuing sampling', which yielded 76 of the 255 cases (Table 2). The total livestock numbers on the 170 farms visited were recorded, allowing for an estimate of minimum prevalence rates of OWS on the two major hosts: cattle $0.3 \%$ (54/17359) and goats $3.2 \%$ (22/696).

'Oriented sampling' generated 179 cases. However, on the larger islands, veterinary clinics recorded no OWS cases in two out of two locations on Borneo (compared with cases discovered in one location investigated more actively by 'collaborative sampling' and 'continuing sampling'), no OWS cases in three out of three locations on Sumatra (compared with cases discovered in all 5 locations investigated more actively), and some OWS cases in one out of three locations on New Guinea (no locations investigated more actively) and, in marked contrast, many OWS cases in 8 out of 10 locations on Java. Table 1, based on 255 cases from widespread locations throughout the Indonesian archipelago, together with Table 3, based on 341 cases from Kediri, represent the most comprehensive record of myiasis cases from Indonesia to date. 


\section{Seasonal distribution of OWS in Kediri regency}

A total of 341 traumatic myiasis cases was recorded in the five districts of Kediri province during 'collaborative sampling' and 'continuing sampling' 2006-2009 (Table 3). These cases were additional to the 255 mentioned previously (Table 1). The annual total was highest in 2007 (29.6\% of the overall total) and lowest in $2008(16.1 \%)$. The highest number of myiasis cases was found in Kandat district $(66.6 \%$ of the overall total) followed by Ngadiluwih (27.6\%). The other districts (Kras, Ringinrejo, Wates) had very few cases, with none reported in 2008.

The mean monthly abundance of myiasis cases in the five districts (based on the mean percentage of the annual total in each month, to enable comparison of years) was relatively stable, fluctuating between $5-13 \%$ of the annual total each month (equivalent to a mean of 5-11 cases per month) (Figure 2). There was variation from year to year, as shown by the standard error (SE) bars, but cases were found in all months with a peak occurring in December-January. If data from December and January were excluded, then in each year except 2006, and also for the combined data (2006-2009), the monthly percentages for February to November did not differ significantly from an expectation of an equal number of cases in each month $\left(\chi^{2}=10.5-14.5, \mathrm{df}=9\right.$; $P=0.10-0.31)$.

Table 1. Number of OWS cases found by 'collaborative sampling', 'continuing sampling' and 'oriented' sampling in different regions of Indonesia

\begin{tabular}{|c|c|c|c|c|c|}
\hline \multirow{2}{*}{ Province } & \multirow{2}{*}{ Island } & \multirow{2}{*}{ Regency/City } & \multicolumn{2}{|c|}{ Species } & \multirow{2}{*}{ Total } \\
\hline & & & C. bezziana & Muscasp & \\
\hline \multirow[t]{2}{*}{ South Borneo } & \multirow[t]{2}{*}{ Borneo } & Tanah Laut & 2 & - & 2 \\
\hline & & Agam & 28 & - & 28 \\
\hline \multirow[t]{2}{*}{ West Sumatra } & & Payakumbuh & 1 & - & 1 \\
\hline & Sumatra & Mungka & 1 & - & 1 \\
\hline \multirow{2}{*}{ Southeast Sumatra } & & Seputih raman & 1 & - & 1 \\
\hline & & Lampung & 11 & 2 & 13 \\
\hline Banten & & Banten & 28 & - & 28 \\
\hline \multirow[t]{2}{*}{ West Java } & & Sukabumi & 2 & - & 2 \\
\hline & & Klaten & 5 & - & 5 \\
\hline \multirow[t]{4}{*}{ Central Java } & & Sleman & 2 & - & 2 \\
\hline & Java & Gunung Kidul & 41 & - & 41 \\
\hline & & Kediri & 69 & - & 69 \\
\hline & & Blitar & 4 & - & 4 \\
\hline \multirow[t]{3}{*}{ East Java } & & Lamongan & 1 & - & 1 \\
\hline & & Jember & 17 & 1 & 18 \\
\hline & Madura & Bangkalan & 1 & - & 1 \\
\hline \multirow{2}{*}{ West Nusa Tenggara } & Lombok & Mataram & 10 & - & 10 \\
\hline & Sumbawa & Sumbawa Besar & 14 & - & 14 \\
\hline \multirow{2}{*}{ East Nusa Tenggara } & Sumba & East Sumba & 4 & - & 4 \\
\hline & Timor & Kupang & 1 & 2 & 3 \\
\hline South Sulawesi & Sulawesi & Makassar & 8 & - & 8 \\
\hline West PNG & PNG & Jayapura & 4 & - & 4 \\
\hline Total & & & 255 & 5 & 260 \\
\hline
\end{tabular}


Table 2 Seventy-six OWS cases discovered by collaborative sampling and continuing sampling in Indonesia and livestock numbers on the affected farms

\begin{tabular}{|c|c|c|c|c|c|c|c|c|}
\hline \multirow{2}{*}{ Year } & \multirow{2}{*}{ Province } & \multirow{2}{*}{ Island } & \multirow{2}{*}{ Regency } & \multirow{2}{*}{$\begin{array}{l}\text { Total } \\
\text { гаıIII }\end{array}$} & \multicolumn{2}{|c|}{ Total population } & \multicolumn{2}{|c|}{ Number of cases } \\
\hline & & & & & Cattle & Goat & Cattle & Goat \\
\hline \multirow[t]{6}{*}{2005} & East Java & Java & Kediri & 32 & 105 & 15 & 2 & 1 \\
\hline & \multirow[t]{2}{*}{ West Nusa Tenggara } & Sumbawa & Sumbawa Besar & 16 & 41 & 67 & 0 & 9 \\
\hline & & Lombok & Mataram & 23 & 34 & 103 & 4 & 8 \\
\hline & East Nusa Tenggara & Sumba & East Sumba & 7 & 20 & 0 & 0 & 0 \\
\hline & South Sulawesi & Sulawesi & Sidrap & 2 & 7003 & 0 & 8 & 0 \\
\hline & West Sumatra & Sumatra & Agam & 12 & 40 & 0 & 4 & 0 \\
\hline \multirow[t]{4}{*}{2007} & Banten & Java & Banten & 10 & 3107 & $300 *$ & 25 & $1^{*}$ \\
\hline & Lampung & Sumatra & Seputih rahman & 2 & 130 & 3 & 0 & 1 \\
\hline & & & Lampung & 25 & 498 & 56 & 0 & 0 \\
\hline & South Borneo & Borneo & Banjar & 25 & 737 & 0 & 0 & 0 \\
\hline \multirow[t]{4}{*}{2009} & West Sumatra & Sumatra & 50 Kota & 1 & 0 & 2 & 0 & 1 \\
\hline & & & Payakumbuh & 3 & 38 & 150 & 0 & 1 \\
\hline & & & Agam & 9 & 31 & 0 & 7 & 0 \\
\hline & Banten & Java & Banten & 3 & 5575 & 0 & 4 & 0 \\
\hline Total & & & & 170 & 17359 & 696 & 54 & 22 \\
\hline
\end{tabular}

*=sheep

\section{Hosts and wound sites of OWS}

Based on the 255 cases discovered by all three types of sampling throughout Indonesia, myiasis occurred both in livestock and dogs (Table 4). The two most commonly infested hosts were cattle, $65.5 \%(167 / 255)$ followed by goats, $22.34 \%$ (57/255). The data also showed that the umbilicus and vulva were the most common wound sites among the hosts, in $23.1 \%$ $(59 / 255)$ and $16.5 \%(42 / 255)$ of cases, respectively. As expected, the majority of umbilical myiasis cases was found in calves $79.7 \%$ (47/59), while vulval myiasis was found mostly in adult cattle, $71.4 \%$ (30/42). Other common wound sites were legs $(12.6 \%, 32 / 255)$ and hooves $(10.6 \%, 27 / 255)$. Of the cases specifying a gender, the number in female hosts $(55.4 \%, 124 / 224)$ was significantly higher than in males $(44.6 \%, 100 / 224)$ $\left(\chi^{2}=4.43\right.$, df $\left.=1, P=0.1088\right)$.

Similarly to the 255 more widespread cases, the two most frequently recorded wound sites in Kediri during the investigation of seasonality (Table 3 ) were the vulva $(25.8 \%, 88 / 341)$, mainly of cows after calving, and umbilicus of newborn calves $(25.2 \%, 86 / 341)$. Unlike in the more widespread survey, where legs were found to be a major wound site (associated especially with poor stabling in Banten), in Kediri leg infestations were grouped in the bottom three $(0.6 \%)$. However, as in the widespread survey, hoof infestations were common, being the only other site with more than $10 \%$ of records (14.4\%, 49/341). 


\section{Mitochondrial typing of OWS flies from wounds}

Of the 520 specimens from Indonesia typed for $c y t b$ haplotype (Wardhana et al. 2012), 69 (13.3\%), and 107 (20.6\%) larvae came from wounds sampled for epidemiological investigations (Tables 3 and 4) in the regencies of Banten and Kediri, respectively (Table 5). Each larva was characterized by only one $c y t b$ haplotype, which is consistent with maternal inheritance of the mitochondrial genome in flies. All haplotypes contained just one long open reading frame (ORF) with the expected stop codon, and so none was identified as a pseudogene that might be inherited chromosomally. The predominant haplotypes in each regency were haplotype CB_bezz06 of sub-lineage 2.2 and haplotype CB_bezz14 of sub-lineage 2.3, which together characterized $89.8 \%$ and $86.9 \%$ of the specimens from Banten (26 wounds) and Kediri (107 wounds), respectively (Table 5).

Most of the wounds in Banten (Table 6) and Kediri (Table 7) contained only one larval instar $(73.1 \%$ and $55.8 \%$, respectively), but some wounds contained different combinations of two larval instars $(15.4 \%$ and $32.6 \%$, respectively) or all three instars $(11.5 \%$ and $11.6 \%$, respectively). The proportion of these three types of wounds was not significantly different (Chisquare $\mathrm{P}>0.05$ ) between the Banten sample with larvae typed for $c y t b$ and the larger sample of 255 wounds from widespread Indonesian locations (Table 8), which comprised wounds with single instars (76.5\%), two instars $(18.4 \%)$ or three instars $(5.1 \%)$. However, the proportion of these three types of wounds was significantly different (Chi-square $\mathrm{P}<0.05)$ between the cyt $b$-typed sample from Kediri and the larger sample of 255 wounds. This difference between Banten and Kediri remained if the analysis included only the wounds on cattle (25 and 26 wounds from Banten and Kediri, respectively) and not those on other hosts (just one wound on a sheep in Banten; but 15 wounds on goats and two wounds on dogs in Kediri) (Table 6 and 7). In Kediri, the ratio of wounds on different hosts was 26 cattle:15 goats: 2 others, which was significantly different (Chi-square $\mathrm{P}<0.05)$ to the ratio for the more general results, namely 167 cattle:57 goats: 31 others (Table 4). Any associations between $c y t b$ haplotypes (or sub-lineages) and hosts were not analysed statistically, because the samples were temporally mixed. However, it can be noted that the two predominant haplotypes from sub-lineage 2.2 (CB_bezz06) and sub-lineage 2.3 (CB_bezz14) were found on each of the main hosts (cattle and goats). These hosts were also infested by each of the predominant haplotypes from sub-lineage 2.1 (CB_bezz02, CB_bezz12) on Sumatra.

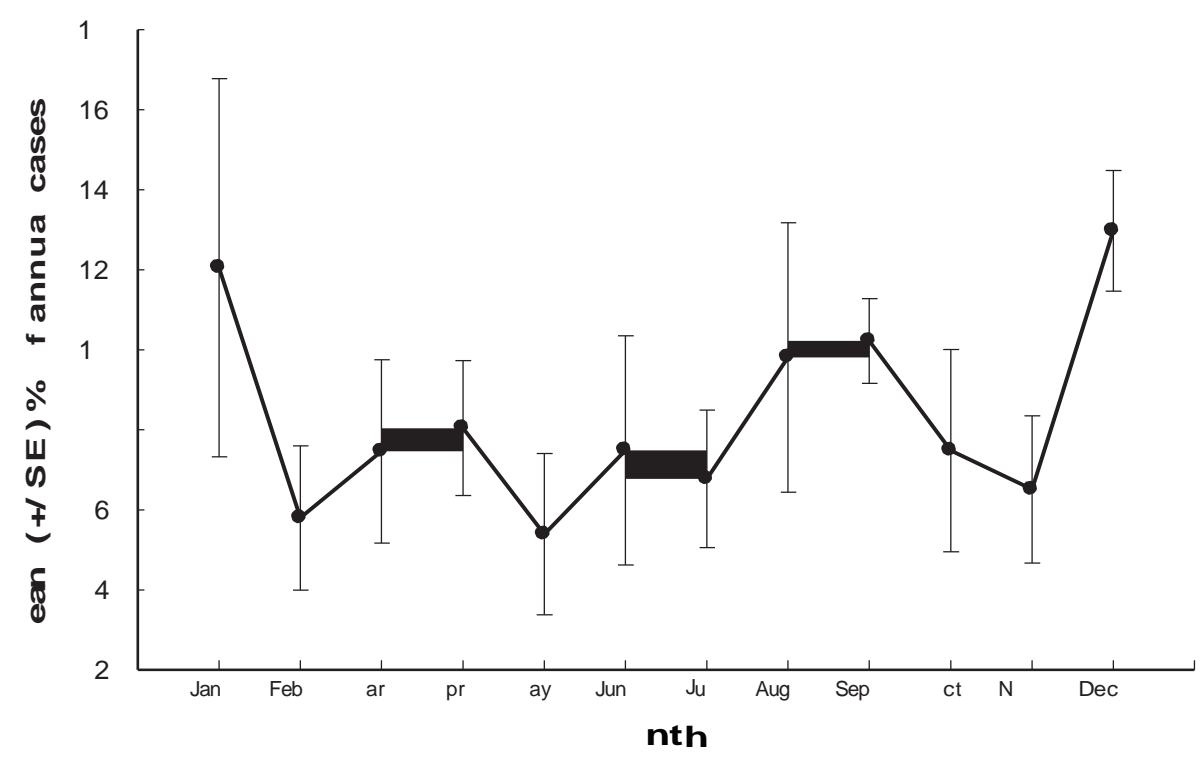

Figure 2. Mean monthly OWS cases as a percentage of the annual total (r SE) in the Kediri regency, 2006-2009. 
Table 3. Number of OWS cases recorded by collaborative sampling and continuing sampling in five districts of Kediri regency

\begin{tabular}{lccccc}
\hline & & \multicolumn{3}{c}{ Years } & Total \\
\cline { 2 - 5 } Districts & 2006 & 2007 & 2008 & 2009 & 227 \\
\hline Kandat & 59 & 66 & 33 & 69 & 94 \\
Ngadiluwih & 18 & 29 & 22 & 25 & 2 \\
Wates & 2 & 3 & - & 1 & 5 \\
Ringinrejo & 2 & 2 & - & 2 & 8 \\
Kras & 5 & 1 & - & 99 & 341 \\
\hline Total & 86 & 101 & 55 & & \\
\hline
\end{tabular}

Table 4. Distribution of myiasis wounds by livestock host and wound location among the 255 OWS cases discovered by 'collaborative sampling', 'continuing sampling' and 'oriented sampling' in Indonesia

\begin{tabular}{|c|c|c|c|c|c|c|c|c|c|c|c|c|c|c|c|}
\hline \multirow{3}{*}{$\begin{array}{l}\text { Wound } \\
\text { location }\end{array}$} & \multicolumn{3}{|c|}{ Gender of host } & \multicolumn{11}{|c|}{ Host species } & \multirow[t]{3}{*}{ Total } \\
\hline & \multirow{2}{*}{$\mathrm{F}$} & \multirow{2}{*}{$\mathrm{M}$} & \multirow{2}{*}{ NR } & \multicolumn{2}{|c|}{ came } & \multicolumn{2}{|c|}{ دittp } & \multicolumn{2}{|c|}{ vial } & \multirow{2}{*}{ Buffalo } & \multirow{2}{*}{ Horse } & \multirow{2}{*}{ Dog } & \multirow{2}{*}{ Pig } & \multirow{2}{*}{ NR } & \\
\hline & & & & Cattle & Calf & Sheep & Lamb & Goat & Kid & & & & & & \\
\hline Umbilicus & 20 & 28 & 11 & 4 & 47 & - & 3 & 3 & 2 & & & & & & 59 \\
\hline Vulva & 42 & - & - & 30 & 2 & 1 & 1 & 7 & 1 & - & - & - & - & - & 42 \\
\hline Leg & 6 & 15 & 11 & 26 & - & - & 1 & - & 1 & 1 & 3 & - & - & - & 32 \\
\hline Hoof & 18 & 8 & 1 & 17 & - & - & - & 9 & - & - & - & - & 1 & - & 27 \\
\hline Tail & 7 & 3 & - & - & - & 5 & - & 2 & 3 & - & - & - & - & - & 10 \\
\hline Udder & 9 & - & - & 8 & - & 1 & - & - & - & - & - & - & - & - & 9 \\
\hline Neck & 3 & 4 & 2 & 5 & 1 & - & - & - & - & - & 2 & 1 & - & - & 9 \\
\hline Prepuce & - & 8 & - & 5 & - & - & - & 2 & 1 & - & - & - & - & - & 8 \\
\hline Muzzle & 2 & 6 & - & 6 & 2 & - & - & - & - & - & - & - & - & - & 8 \\
\hline Rectum & 4 & 3 & - & - & 1 & 3 & - & 3 & - & - & - & - & - & - & 7 \\
\hline Mouth & 2 & 5 & - & - & 3 & - & - & 4 & - & - & - & - & - & - & 7 \\
\hline Ear & 4 & 1 & - & 2 & - & - & - & 2 & - & - & - & 1 & - & - & 5 \\
\hline Abdomen & - & 7 & 1 & - & - & - & - & 5 & 2 & - & - & 1 & - & - & 8 \\
\hline Horn & 2 & 2 & - & 1 & - & - & - & 3 & - & - & - & - & - & - & 4 \\
\hline Hip & 1 & 3 & - & - & 1 & - & - & 3 & - & - & - & - & - & - & 4 \\
\hline Back & - & 3 & 1 & - & - & - & - & 1 & - & - & - & 3 & - & - & 4 \\
\hline Eye & 2 & 1 & - & 2 & 1 & - & - & - & - & - & - & - & - & - & 3 \\
\hline $\begin{array}{l}\text { Upper } \\
\text { Head }\end{array}$ & - & 2 & - & 1 & - & - & - & - & - & - & - & 1 & - & - & 2 \\
\hline Thorax & 1 & - & - & - & - & - & - & 1 & - & - & - & - & - & - & 1 \\
\hline Scapula & - & 1 & - & 1 & - & - & - & - & - & - & - & - & - & - & 1 \\
\hline N R & 1 & - & 4 & 1 & - & - & - & 2 & - & - & - & - & - & 2 & 5 \\
\hline Total & 124 & 100 & 31 & 109 & 58 & 10 & 5 & 47 & 10 & 1 & 5 & 7 & 1 & 2 & 255 \\
\hline
\end{tabular}

Comment: NR : Not Recorded 
Table 5. Frequencies of mitochondrial cyt b haplotype in larvae of the OWS fly sampled from livestock wounds in Banten and Kediri regencies

\begin{tabular}{|c|c|c|c|c|c|}
\hline \multicolumn{2}{|c|}{ Mitochondrial $c y t b$ typing } & \multicolumn{2}{|c|}{ Banten sample } & \multicolumn{2}{|c|}{ Kediri sample } \\
\hline Haplotype CB_bezz & Sub-lineage & $\begin{array}{c}\text { Number of } \\
\text { larvae }\end{array}$ & $\begin{array}{l}\text { Proportion, or } \\
\text { haplotype frequency }\end{array}$ & $\begin{array}{l}\text { Number of } \\
\text { larvae }\end{array}$ & $\begin{array}{c}\text { Proportion, or } \\
\text { haplotype frequency }\end{array}$ \\
\hline 06 & 2.2 & 35 & 0.507 & 66 & 0.617 \\
\hline 25 & 2.2 & 2 & 0.029 & 0 & - \\
\hline 26 & 2.2 & 2 & 0.029 & 0 & - \\
\hline 27 & 2.2 & 2 & 0.029 & 0 & - \\
\hline 37 & 2.2 & 0 & - & 3 & 0.028 \\
\hline 14 & 2.3 & 27 & 0.391 & 27 & 0.252 \\
\hline 15 & 2.3 & 0 & 0.000 & 2 & 0.019 \\
\hline 22 & 2.3 & 1 & 0.015 & 0 & - \\
\hline 36 & 2.3 & 0 & - & 9 & 0.084 \\
\hline Total larvae & & 69 & & 107 & \\
\hline Total wounds & & $26^{\mathrm{a}}$ & & $43^{b}$ & \\
\hline
\end{tabular}

${ }^{\mathrm{a}}$ See Table $6,{ }^{\mathrm{b}}$ see Table 7

Table 6 Different complements of mitochondrial cyt ${ }^{\mathrm{E}}$ haplotypes (CB_Bezznn) in larvae $\mathrm{D}$ of the OWS fly from single wounds on 26 livestock in Banten regency

\begin{tabular}{|c|c|c|c|c|c|c|c|}
\hline \multirow[t]{2}{*}{ Haplotype complement } & \multicolumn{3}{|c|}{$\begin{array}{l}\text { Larval instars with haplotype } \\
\text { complement in each wound }\end{array}$} & \multicolumn{3}{|c|}{$\begin{array}{c}\text { Numbers of each host with such } \\
\text { wounds }\end{array}$} & \multirow{2}{*}{$\begin{array}{c}\text { Total wounds } \\
\text { All hosts }\end{array}$} \\
\hline & L1 & L2 & L3 & Cattle & Sheep (goats) & Dogs & \\
\hline & \multicolumn{7}{|c|}{ Single larval instar in each wound } \\
\hline $\mathrm{HC} 2$ & $\mathrm{~b}$ & 06 & - & 1 & 0 & 0 & 1 \\
\hline $\mathrm{HC} 3$ & - & - & 06 & 10 & 1 & 0 & 11 \\
\hline $\mathrm{HC} 4$ & - & - & 14 & 5 & 0 & 0 & 5 \\
\hline HC 6 & - & - & 06,14 & 1 & 0 & 0 & 1 \\
\hline $\mathrm{HC} 8$ & - & - & 14,22 & 1 & 0 & 0 & 1 \\
\hline \multirow[t]{2}{*}{ Sub-totals } & & & & 18 & 1 & 0 & 19 \\
\hline & \multicolumn{7}{|c|}{ Multiple larval instars in each wound } \\
\hline $\mathrm{HC} 9$ & 06,14 & 06 & - & 1 & 0 & 0 & 1 \\
\hline HC 13 & - & 06 & 25 & 1 & 0 & 0 & 1 \\
\hline HC 16 & - & 14 & 14 & 2 & 0 & 0 & 2 \\
\hline HC 20 & 06 & 06 & 06 & 1 & 0 & 0 & 1 \\
\hline $\mathrm{HC} 22$ & 14 & 14 & 06,14 & 1 & 0 & 0 & 1 \\
\hline $\mathrm{HC} 23$ & 27 & 06,14 & 26 & 1 & 0 & 0 & 1 \\
\hline Sub-totals & & & & 7 & 0 & 0 & 7 \\
\hline
\end{tabular}

a Two larvae of each instar were individually typed from each wound; b Not present

L1 1st instar; L2 2nd instar, L3 3rd instar 
Table 7. Different complements of mitochondrial cyt $b$ haplotypes (CB_bezzNN) in larvae ${ }^{\text {a }}$ of the OWS fly from single wounds on 43 livestock in Kediri regency

\begin{tabular}{|c|c|c|c|c|c|c|c|}
\hline \multirow{2}{*}{$\begin{array}{l}\text { Haplotype } \\
\text { complement }\end{array}$} & \multicolumn{3}{|c|}{$\begin{array}{l}\text { Larval instars with haplotype } \\
\text { complement in each wound }\end{array}$} & \multicolumn{3}{|c|}{$\begin{array}{c}\text { Numbers of each host with such } \\
\text { wounds }\end{array}$} & \multirow{2}{*}{$\begin{array}{c}\text { Total wounds } \\
\text { All hosts }\end{array}$} \\
\hline & L1 & $\mathrm{L} 2$ & L3 & Cattle & Goats & Dogs & \\
\hline & \multicolumn{7}{|c|}{ Single larval instar in each wound } \\
\hline$\overline{\mathrm{HC}} 1$ & 06 & $-b$ & - & 1 & 0 & 0 & 1 \\
\hline $\mathrm{HC} 2$ & - & 06 & - & 3 & 0 & 0 & 3 \\
\hline $\mathrm{HC} 3$ & - & - & 06 & 8 & 6 & 0 & 14 \\
\hline $\mathrm{HC} 4$ & - & - & 14 & 1 & 3 & 0 & 4 \\
\hline HC 5 & - & - & 36 & 1 & 0 & 0 & 1 \\
\hline $\mathrm{HC} 7$ & - & - & 06,36 & 0 & 1 & 0 & 1 \\
\hline \multirow[t]{2}{*}{ Sub-totals } & & & & 14 & 10 & 0 & 24 \\
\hline & \multicolumn{7}{|c|}{ Multiple larval instars in each wound } \\
\hline HC 10 & 14 & 06 & - & 1 & 0 & 0 & 1 \\
\hline HC 11 & 06 & - & 06 & 1 & 0 & 0 & 1 \\
\hline HC 12 & - & 06 & 06 & 1 & 0 & 0 & 1 \\
\hline HC 13 & - & 06 & 14 & 2 & 0 & 0 & 2 \\
\hline HC 14 & - & 06 & 14,36 & 1 & 1 & 0 & 2 \\
\hline HC 15 & - & 06 & 36 & 0 & 1 & 0 & 1 \\
\hline HC 17 & - & 14 & 06 & 2 & 0 & 0 & 2 \\
\hline HC 18 & - & 15 & 06 & 1 & 0 & 0 & 1 \\
\hline HC 19 & - & 36 & 36 & 1 & 0 & 0 & 1 \\
\hline $\mathrm{HC}-$ & - & 37 & $\mathrm{NR}^{\mathrm{c}}$ & 0 & 0 & 1 & 1 \\
\hline $\mathrm{HC}-$ & - & NR & 06 & 0 & 1 & 0 & 1 \\
\hline HC 21 & 06 & 14 & 14 & 0 & 1 & 0 & 1 \\
\hline HC 24 & 37 & 06 & 06 & 0 & 0 & 1 & 1 \\
\hline $\mathrm{HC}-$ & NR & NR & 14 & 1 & 0 & 0 & 1 \\
\hline $\mathrm{HC}-$ & NR & 06 & 14 & 0 & 1 & 0 & 1 \\
\hline $\mathrm{HC}-$ & NR & 06 & 06,14 & 1 & 0 & 0 & 1 \\
\hline Sub-totals & & & & 12 & 5 & 2 & 19 \\
\hline
\end{tabular}

a Two larvae of each instar were individually typed from each wound; b Not present ; c No result

L1 1st instar; L2 2nd instar, L3 3rd instar

\section{Multiple OWS infestations of the same wound}

Multiple infestations of a wound were detected by the presence of more than one larval instar and/or more than one cyt $b$ haplotype of the OWS fly. Each larva contained only one identified cyt $b$ haplotype, and only two larvae of each instar were usually typed from each wound. Therefore the detection of all haplotypes in a wound was not guaranteed, and the results provide a minimum estimate of multiple infestations.
Considering only the presence of single or multiple larval instars, not of any $c y t b$ haplotype diversity, infestations with third instars alone formed the most common type of myiasis recorded among 255 wounds from widespread locations $(65.5 \%)$, followed by multiple infestations with both second and third instar larvae (15.7\%) (Table 8). When comparing the proportions of occurrence of single- and multi-instar infestations, there were no significant differences (Chisquare $\mathrm{P}>0.05$ ) between the six regencies with large 
numbers of OWS infestations (Agam and Lampung on Sumatra; Banten, Gunung Kidul, Kediri and Jember on Java; Table 1), between the predominant hosts (cattle, goats and sheep) (Table 8), or between the five most infested sites on hosts (umbilicus, vulva, leg, hoof and tail) (Table 4). However, there were insufficient data to perform multivariate analyses to identify any covariation between geographical region, host species, wound location and season.

Furthermore, multiple infestations are likely to be underestimated because, in well sampled locations, $c y t$ $b$ typing indicates that secondary infestations can occur over periods short enough to produce wounds occupied by only a single instar, i.e. with two or more haplotypes present in the same instar. This was the case for three wounds with only third instar larvae but two cyt $b$ haplotypes (two in Banten, one in Kediri) and five multi-instar wounds with two cyt $b$ haplotypes found in larvae of the same instar (three in Banten, two in Kediri) (Table 6 and 7).

There was no evidence for any association of a $c y t b$ haplotype or sub-lineage with primary or secondary infestation. Based on 23 fully characterized multi-instar wounds (Table 6 and 7), only haplotypes of one sublineage were found in all the instars from 8 wounds; 6 wounds contained the oldest instars with haplotype CB_bezz06 (or another haplotype of sub-lineage 2.2) in the absence of haplotype CB_bezz14 (or another haplotype of sub-lineage 2.3); the reverse was true for 7 wounds; and, both sub-lineages were present in the oldest instars from two wounds.

\section{Discussion}

\section{Geographical distributions of myiasis caused by fly species and their genetic lineages}

The OWS fly was the primary cause of traumatic myiasis of livestock in Indonesia, and no larvae of the facultative parasite Chrysomya megacephala, the sister species, were found in any of the wounds, despite this species being widespread in the country (Wardhana et al. 2012). Only a very few cases of chicken myiasis caused by Musca species were recorded. Myiasis of poultry by species of Calliphoridae is generally rare, reported for Lucilia sericata [on turkeys in Iraq (AlKhalidi \& Shareef 1985) and on geese in Hungary (Farkas et al. 2001)] and for Cochliomyia macellaria and Phaenicia species [on chickens in Panama (Bermúdez et al. 2007)] and the OWS fly [on chickens in India (Jeyathilakan et al. 2011)].

In the present study, more larvae and myiasis cases were found in Kediri, East Java (27.1\% of 255) than in any other location. However, we believe that the results were correlated with sampling intensity and local veterinarians' interest in myiasis and their enthusiasm for surveillance, rather than with case prevalence or the OWS fly's population density. Most infestations discovered 2002-2009 came from local veterinary clinic services participating in the 'collaborative sampling' and 'continuing sampling' schemes, such as in Kediri, rather than our 'oriented sampling' scheme, which was ineffective outside Java. All three sampling schemes

Table 8. Numbers of myiasis wounds on different livestock hosts that contained single and multiple larval instars among the 255 OWS cases discovered by 'collaborative collections', 'continuing collections' and 'oriented collections' in Indonesia

\begin{tabular}{|c|c|c|c|c|c|c|c|c|}
\hline \multirow{2}{*}{ Host species } & \multicolumn{7}{|c|}{ Larval instars ${ }^{a}$} & \multirow{2}{*}{ Total } \\
\hline & L1 & L2 & $\mathrm{L} 3$ & $\mathrm{~L} 1+\mathrm{L} 2$ & $\mathrm{~L} 1+\mathrm{L} 3$ & $\mathrm{~L} 2+\mathrm{L} 3$ & $\mathrm{~L} 1+\mathrm{L} 2+\mathrm{L} 3$ & \\
\hline Cattle & 6 & 13 & 105 & 2 & 3 & 30 & 8 & 167 \\
\hline Sheep & 1 & 1 & 12 & - & - & 1 & - & 15 \\
\hline Goat & 3 & 4 & 38 & 2 & - & 6 & 4 & 57 \\
\hline Horse & - & - & 5 & - & - & - & - & 5 \\
\hline Buffalo & - & - & 1 & - & - & - & - & 1 \\
\hline Dog & - & - & 3 & - & - & 3 & 1 & 7 \\
\hline Pig & - & - & 1 & - & - & - & - & 1 \\
\hline $\mathrm{NR}^{\mathrm{b}}$ & - & - & 2 & - & - & - & - & 2 \\
\hline Total & 10 & 18 & 167 & 4 & 3 & 40 & 13 & 255 \\
\hline
\end{tabular}

${ }^{\text {a }}$ L1 $1^{\text {st }}$ instar; L2 $2^{\text {nd }}$ instar, L3 $3^{\text {rd }}$ instar

${ }^{b}$ NR Not recorded 
were variants of passive case detection, which cannot be relied upon (Vreysen 2005) to demonstrate changes in the population density of screwworm in an area. It is more likely to be a reflection of reporting efficiency and the level of farmer cooperation.

The OWS fly in Indonesia is characterised by mitochondrial DNA haplotypes grouped into four sublineages, with the Asian mainland sub-lineage 2.1 predominating on Sumatra in the west, sub-lineages 2.2 and 2.3 predominating on Java, sub-lineage 2.2 predominating on the smaller islands of Wallacea (Nusa Tenggara and Maluku), and sub-lineage 2.4 predominating on New Guinea in the east (Wardhana et al. 2012). The samples analysed in the current report reflected this pattern.

\section{Seasonal and environmental distribution of $O W S$ myiasis infestations}

The surveillance data from 2006-2009 showed numbers of reported myiasis cases in the range of 55101 per year in five districts of Kediri and demonstrated that traumatic myiasis is a major problem for small farmers in this regency of East Java. Kandat and Ngadiluwih districts showed a higher number of cases of myiasis than other districts (Table 3). These two districts are only about $2 \mathrm{~km}$ from the animal clinic where the data was collected, making it more likely that traditional farmers would report their livestock problems to the veterinarians. Wates, Ringinrejo and Kras were approximately $10 \mathrm{~km}$ from the clinic and the larger farmers in those districts reported their livestock problems to private veterinarians who do not maintain an accurate record of myiasis cases. Therefore the myiasis problem is likely to be significantly greater than suggested by the reported data.

Even though cases could be found in every month during the four-year study period, there was a slight seasonal trend for myiasis cases to peak in Kediri in December-January (Figure 1), during the rainy season (http://www.worldweatheronline.com). This finding is consistent with what is known about the seasonality of OWS in other Asian regions. Although the peak of myiasis cases might occur in different months in different geographical regions, the peak months everywhere experience similar climatic conditions, i.e. moderately high temperature and humidity (Sutherst et al. 1989). In this way, the highest number of OWS cases in Iraq and Oman occurred in the cooler months of December-March (Al-Taweel et al. 2000; Spradbery 1992; Siddig et al. 2005), and cases in Saudi Arabia usually peak in March-May when there is higher rainfall (Alahmed et al. 2006). However, even if temperature and humidity are major determinants of the seasonality of the OWS fly, many other environmental factors can directly or indirectly influence its distribution, such as human population density, cattle density, elevation and tree cover (Wardhana et al. 2014).

Seasonality is unlikely to have significantly affected our investigations into host preferences and wound locations of OWS (see the next section), because most of the widespread cases came from the larger islands, where seasonal differences in climate are small and similar to those in Kediri on Java (Wardhana et al. 2014).

\section{Hosts of traumatic myiasis and wound sites}

The predominant host animals attacked by $C$. bezziana in Indonesia in this study were cattle $(65.5 \%)$ followed by goats (22.4\%) (Table 2 and 4). However, this in itself does not necessarily imply that cattle are more susceptible to myiasis or are the preferred host because the numbers of livestock at risk of infestation in the same herds/flocks need to be taken into account. Where available, these data suggest that goats are at much greater risk of OWS infestation than cattle, with $5.3 \%(21 / 396)$ of goats infested compared to $0.31 \%$ $(54 / 17,359)$ of cattle in the same geographical areas (Table 2). The goat data were skewed by the relatively high level of infestation of goats in West Nusa Tenggara $(17 / 170=10 \%$; Table 2$)$. Clearly more extensive surveys of OWS myiasis prevalence are required in Indonesia to definitively report on OWS host preferences and the risks of myiasis infestation by OWS to different hosts in different regions of the country.

The major wound sites recorded in this study were the umbilicus of calves and the vulva of cattle, associated with calving. Calving is clearly a major risk period for infestation by the OWS fly and a period in which farmers should regularly check their livestock. The same is true for NWS fly, Cochliomyia hominivorax, but wound sites are also clearly related to environmental factors. Hence in the Yucatan Peninsula of Mexico, the most frequently observed sites of NWS infestations on cattle were related to vampire bat bite sites on the neck and shoulders, umbilicus sites being third numerous (Thomas 1987). Other common sites of myiasis in our study were the leg and hoof, possibly attributed to the poor condition of the stables: those with slippery and dirty floors caused some livestock to be wounded in their limbs or to develop foot-rot (Muharsini et al. 2010; personal observations in this study).

Hall et al. (2009a) noted that identification of wound sites is important in the treatment of myiasis because it indicates the best sites for the potential application of topical prophylactics for control of myiasis. Giving treatment preferentially to the hind 
quarters of the host would assist the protection of organs such as the genitalia, anus, udder and umbilicus.

\section{Multiple infestations}

Mature, third instar larvae were those most frequently removed from wounds, suggesting that farmers generally neglected to check their livestock as regularly as they should or simply overlooked smaller wounds with immature larvae during the first 5-6 days after egg laying. In the current study, the proportions of livestock wounds with multiple larval instars were somewhat similar in cattle $(42 / 167=25.7 \%)$ and goats $(12 / 57=21.1 \%)$. A substantial number of wounds were found with two larval instars $(18.4 \%, 47 / 255)$ and a smaller number with all three instars $(5.1 \%, 13 / 255)$ in sites as varied as hoof, prepuce, vulva, umbilicus, muzzle, thigh, ear and head (Table 8). Infestations in host sites that are difficult to handle and inspect would encourage the occurrence of multiple infestations. For example, although only a few prepuce infestations were recorded, a high proportion had multiple-instar infestations $(75 \%, 6 / 8)$. Multiple infestations are underestimated if based only on the presence of multiple larval instars, because mitochondrial DNA typing demonstrated that larvae of the same instar often originate from two or more mothers, which must lay their eggs within 1-36 hours of each other.

\section{Overlooked economic importance of $O W S$}

This study clearly demonstrated that cases of traumatic myiasis caused by the OWS fly are widespread in Indonesia and occur frequently, despite the relatively small number of cases reported in the literature and by veterinary services. One reason for this might be the low mortality associated with myiasis if treatment is timely. Myiasis is not classified nationally among the diseases of strategic importance, such as anthrax, brucellosis, rabies, foot and mouth disease and avian influenza. Therefore, myiasis treatments are left to livestock owners to apply. Nevertheless, if infested livestock are not treated appropriately they can die or suffer permanent disability, and so the economic effects on small farms, with small numbers of livestock, can be relatively severe. Although our survey was completed in 2009, the dangers of screwworm myiasis still persist in Indonesia, not only to wild and domesticated animals, but also to humans (Hidayat et al. 2016).

The Indonesian government has yet to analyse the economic impact of OWS infestations on the livestock industry, but the impact will be significant if case prevalences are similar to those in adjacent Malaysia.
Grindle et al. (2001) showed that the total annual loss of livestock production due to myiasis infestations in Malaysia was around RM 18 million (US \$4.7 million). Similarly, Nor (2002) estimated that the annual losses to the Malaysian livestock industry due to myiasis infestation were about RM 23 million (US \$ 6 million). Taking into account the plans of the Malaysian government to expand animal production, the economic impact was projected to reach RM 32 million (US \$ 8.5 million) in 2005 and RM 50 million (US \$ 13.1 million) in 2010 (Grindle et al. 2001). These estimates are similar to those from an economic analysis of the impact of Cochliomyia hominivorax in Cuba (Grindle et al. 2001).

A cost-benefit analysis of OWS myiasis prevention and control is required, in order to assess the economic effects on national and international trade of livestock. The epidemiological data presented in the current report provide a useful baseline of the host and spatiotemporal distribution of OWS in Indonesia, on which to build a more robust picture of monthly transmission, in order to support a control or eradication programme using SIT as a component of Integrated Pest Management (IPM). Accurate prevalence and incidence data are required, based on standardised surveillance of randomized samples of livestock, because current case densities reflect variable surveillance activity. This makes it difficult for Indonesia to regularly submit surveillance data to the World Animal Health Information Database (WAHID).

\section{CONCLUSION}

The epidemiology of traumatic myiasis caused by the OWS fly in Indonesia is complex, with multiple infestations of wounds frequent. The plasticity in host selection demonstrated by all mitochondrial lineages of the OWS fly in Indonesia is clearly advantageous to this species, as is its lack of marked seasonality, both of which facilitate colonization of new areas and diverse hosts.

\section{ACKNOWLEDGEMENT}

The present study received financial support from International Atomic Energy Agency (IAEA, Austria) collaborated with the Natural History Museum and Indonesian Agency for Agricultural Research and Development (IAARD). The authors also thank Dr. Udo Feldman of IAEA for his interest and those colleagues who assisted in fieldwork in Indonesia: Drhs Eliyus Saputra, Martono, Indarto, Hendri, Catur Budi Djatmiko, Retno Widyastuti and Agus Sumatri. 


\section{REFERENCES}

Al-Khalidi NW, Shareef AM. 1985. Myiasis in a Turkey. Avian Dis. 29:1235-1238.

Al-Taweel AA, Al-Izzi MAJ, Jassim FA. 2000. Incidence of Old World screwworm fly, Chrysomya bezziana in Iraq. Area-wide control of fruit flies and other insect pests. Pulau Pinang (Malaysia): Universiti Sains Malaysia.

Alahmed AM, Al Dawood AS, Kheir SM. 2006. Seasonal activity of flies causing myiasis in livestock animals using sticky traps baited with swormlure-4 in Riyadh region, Saudi Arabia. Sci J King Faisal Univ (Basic Appl Sci). 7:109-119.

[BMKG] Badan Meteriologi, Klimatologi dan Geofisika. 2017. Prakiraan Cuaca Kabupaten Kediri Propinsi Jawa Timur. [accessed 2017 Mar 4]. http://www.bmkg.go.id/ cuaca/prakiraan-cuaca-indonesia.bmkg?Prov $=12 \&$ NamaProv=JawaTimur

Bermúdez SE, Espinosa JD, Cielo AB, Clavel F, Subía J, Barrios S, Medianero E. 2007. Incidence of myiasis in Panama during the eradication of Cochliomyia hominivorax (Coquerel 1858, Diptera: Calliphoridae) (2002-2005). Mem Inst Oswaldo Cruz. 102:675-679.

Chomczynski P, Mackey K, Drews R, Wilfinger W. 1997. DNAzol: a reagent for the rapid isolation of genomic DNA. Biotechniques. 22:550-3.

Cox JSH, Vreysen MJB. 2005. Use of Geographic information systems and spatial analysis in area-wide integrated pest management programmes that integrate the sterile insect Technique. In: Sterile Insect Tech. Berlin/Heidelberg: Springer-Verlag; p. 453-477.

Farkas R, Szántó Z, Hall M. 2001. Traumatic myiasis of geese in Hungary. Vet Parasitol. 95:45-52.

Grindle J, Tafsir S, Hamdan A. 2001. Economic losses from Old World Screwworm in Malaysia and Benefit cost analysis of eradication program. Malaysia: Internal Department of Veterinary Services Malaysia.

Hall M, Testa J, Smith L, Adams Z, Khallaayoune K, Sotiraki S, Stefanakis A, Farkas R, Ready P. 2009. Molecular genetic analysis of populations of Wohlfahrt's wound myiasis fly, Wohlfahrtia magnifica, in outbreak populations from Greece and Morocco. Med Vet Entomol. 23:72-79.

Hall MJ, Edge W, Testa JM, Adams ZJ, Ready PD. 2001. Old World screwworm fly, Chrysomya bezziana, occurs as two geographical races. Med Vet Entomol. 15:393-402.

Hall MJR. 2008. New world screwworm (Cochliomyia hominivorax) and Old world screwworm (Chrysomya bezziana). Chapter 2.1.10. . OIE Terrestrial Manual 2008:265-275.

Hall MJR, Wall RL, Stevens JR. 2016. Traumatic myiasis: A neglected disease in a changing world. Annu Rev Entomol. 61:159-176.

Hall MJR, Wardhana AH, Shahhosseini G, Adams ZJO, Rady PD. 2009. Genetic diversity of populations of Old
World screwworm fly, Chrysomya bezziana, causing traumatic myiasis of livestock in the Gulf region and implications for control by sterile insect technique. Med Vet Entomol. 23:51-58.

Hidayat R, Rahaju P, Surjotomo H, Murdiyo M. 2016. Laporan kasus: Myiasis pada peristoma trakeostomi. J Kedokteran Brawijaya. 29:95-98.

Jeyathilakan N, Kavitha S, Murugadas V, A BS. 2011. Traumatic myiasis in a Rhode Island Red cock. J Vet Parasitol. 25:79-81.

Kraneveld FC, Pettinga JJ. 1949. Myiasis bij het paard. Hemera Zoa. 56:296-298.

Kraneveld FC, Schaaf AVD. 1937. Een myiasis van de klauwen en hun ongeving by runderen. Ned Ind B1 Dierg. 49:360-369.

Lindquist DA, Abusowa M, Hall MJ. 1992. The New World screwworm fly in Libya: a review of its introduction and eradication. Med Vet Entomol. 6:2-8.

Mahon RJ. 2002. The Malaysian project - entomological report. In: Proc Screw-worm Fly Emerg Prep Conf. Canberra (Aust): Agriculture, Fisheries and Forestry; p. 140-151.

Muharsini S, Wardhana AH, Maryam R. 2010. Collection and incidence of myiasis caused by the Old World Screwworm fly, Chrysomya bezziana, in West Java Indonesia. In: IAEA Coord Res Meet. Viena (Austria): International Atomic Energy Agency.

Mustika AA, Hadi UK, Wardhana AH, Rahminiwati M, Wientarsih I. 2016. The efficacy of larvasides of leaves of Yam Bean (Pachyrhizuserous) as botanical insecticides against fly; arvae myiasis Chrysomya bezziana. IOSR J Pharm. 6:78-81.

Nor MN. 2002. Screw-worm fly - the next step for Malaysia. Proceedings of the Screw-worm Fly Emergency Preparedness Conference. Canberra (Aust): Department of Primary Industries and Fisheries. p. 120-129.

Partoutomo S. 2000. Epidemiologi dan pengendalian myiasis di Indonesia. Wartazoa. 10:20-27.

Ready PD, Testa JM, Wardhana AH, Al-Izzi M, Khalaj M, Hall MJR. 2009. Phylogeography and recent emergence of the Old World screwworm fly, Chrysomya bezziana, based on mitochondrial and nuclear gene sequences. Med Vet Entomol. 23:43-50.

Robinson AS, Vreysen MJB, Hendrichs J, Feldmann U. 2009. Enabling technologies to improve area-wide integrated pest management programmes for the control of screwworms. Med Vet Entomol. 23:1-7.

Siddig A, Al Jowary S, Al Izzi M, Hopkins J, Hall MJR, Slingenbergh J. 2005. Seasonality of Old World screwworm myiasis in the Mesopotamia valley in Iraq. Med Vet Entomol. 19:140-150.

Sigit SH, Partoutomo S. 1991. Myiasis in Indonesia. Bull Off Int Epizoot. 93:140-150. 
Spradbery J. 1992. Screwworm fly: an Australian perspective. Aust Vet J. 9:88.

Spradbery J, Tozer R, Robb J, Cassells P. 1989. The screwworm fly Chrysomya bezziana Villeneuve (Diptera, Calliphoridae) in a sterile insect release trial in Papua New Guinea. Res Popul Ecol. 31:353-366.

Sukarsih, Tozer RS, Knox MR. 1989. Collection and case incidence of the Old World screwworm fly, Chrysomya bezziana, in three localities in Indonesia. Penyakit Hewan. 21:114-117.

Sutherst RW, Spradbery JP, Maywald GF. 1989. The potential geographical distribution of the Old World screw-worm fly, Chrysomya bezziana. Med Vet Entomol. 3:273-280.

Thomas DB. 1987. Incidence of screwworm (Diptera: Calliphoridae) and torsalo (Diptera: Cuterebridae) myiasis on the Yucatan Peninsula of Mexico. J Med Entomol. 24:498-502.

Vargas-Terán M, Hofmann HC, Tweddle NE. 2005. Impact of screwworm eradication programmes using the sterile insect technique. In: Dyck VA, Hendrichs J, Robinson AS, editors. Sterile Insect Tech. Berlin/Heidelberg: Springer-Verlag; p. 629-650.

Vreysen MJB. 2005. Monitoring sterile and wild insects in area-wide integrated pest management programmes. In: Dyck VA, Hendrichs J, Robinson AS, editors. Sterile Insect Technique Principles and Practice in Area-Wide Integrated Pest Management. Dordrecht (Nedherland): Springer. p. 325-361.

Wardhana A. 2006. Chrysomya bezziana penyebab myiasis pada hewan dan manusia: Permasalahan dan penanggulangannya. Wartazoa. 16:146-259.
Wardhana AH, Cecchi G, Muharsini S, Cameron MM, Ready PD, Hall MJR. 2014a. Environmental and phylogeographical determinants of the distribution of the Old World screwworm fly in Indonesia. Acta Trop. 138:S62-S68.

Wardhana AH, Diana N. 2014b. Biolarvacidal activity of methanol extract of Kipahit leaves (Tithonia diversifolia) against larvae of Chrysomya bezziana fly. JITV. 19:43-51.

Wardhana AH, Hall MJR, Mahamdallie SS, Muharsini S, Cameron MM, Ready PD. 2012. Phylogenetics of the Old World screwworm fly and its significance for planning control and monitoring invasions in Asia. Int J Parasitol. 42:729-738.

Wardhana AH, Muharsini S, Suhardono. 2003. Koleksi dan kejadian myasis yang disebabkan oleh Old World Screwworm Fly, Chrysomya bezziana di daerah endemik di Indonesia. Mathius I-W, Setiadi B, Sinurat AP, Ashari, Darmono, Wiyono A, Purwadaria T, editors. Proceeding of National Seminar on Livestock Production and Veterinary Technology. Bogor (Indones): Indonesian Center for Animal Research and Development. p. 235-239.

Welch JB, Hall MJR. 2013. New World screwworm (Cochliomyia hominivorax) and Old World screwworm (Chrysomya bezziana). Chapter 2.1.10. In: Manual of Diagnostic Tests and Vaccines for Terrestrial Animals (mammals, birds and bees). 7th Edition, Volume 1. Paris (France): OIE, World Organization for Animal Health.

Wientarsih A, Mustika AA, Wardhana AH, Darmakusumah D, Sutardi LN. 2017. Daun Binahong (Andredera cordifolia Steenis) sebagai alternatif insektisida terhadap miasis yang disebabkan lalat Chrysomya bezziana. J Vet. 18:121-127. 